\title{
STRUCTURAL EQUATION TEST OF ENTREPRENEURIAL EDUCATION AND ENTREPRENEURIAL INTENTIONS AMONG NIGERIAN UNDERGRADUATE STUDENTS
}

\author{
Chidera Christian Ugwuanyi \\ University of Nigeria, Enugu Campus \\ Pamela Ifeoma Nwagbo \\ University of Nigeria, Enugu Campus \\ \& \\ Ikechukwu Joseph Attamah \\ University of Nigeria, Enugu Campus
}

\begin{abstract}
The purpose of this paper is to examine the causal relationship between entrepreneurial education and entrepreneurial intention among undergraduates. The paper investigates how the outcome of an effective entrepreneurial education system-attitude, skills and knowledge could affect the intentions of the students to choosing entrepreneurship as a career choice. The study was conducted in Enugu state, Nigeria among university undergraduates. A total of 250 students were engaged but only 196 valid responses were gathered. The structural model and the hypotheses were tested using partial least square structural equation modelling (PLS-SEM) approach in SmartPLS M2.0 software. Our findings reveal that the proposed determinants all bear positive relationships with entrepreneurial intention in varying degrees. Also we found entrepreneurial knowledge to have a direct impact on entrepreneurial attitude. Managerial and practical implications were made as well as future research avenues suggested.
\end{abstract}

Keywords: Entrepreneurship, Entrepreneurial Intention, Entrepreneurial Education, Youth Unemployment, Partial Least Square-Structural Equation Modelling (PLS-SEM)

\section{Introduction}

The current concerns about the uncertain future due to a long economic depression and global economic crisis are spreading throughout our society. Moreover, along with the trend in industrial-scale downsizing and profit generation with a small manpower cost, increasing concerns about the worsening youth unemployment due to these factors are deepening (Park, 2017). Youth unemployment in Nigeria has continued to be on the increase amidst concerted efforts by government and the private sector to ameliorate this condition. In 2018, the rate of unemployment rose from $21.8 \%$ in the first quarter to $22.7 \%$ in the second quarter and $23.1 \%$ in the third quarter (NBS, 2018), an indication of an increasing rate of unemployment and lack of faith in paid employment to absolve the teeming population of Nigerian graduates.

Governments at different levels and institutions of higher learning believe that entrepreneurship exerts a positive influence on job creation, reduction in graduate unemployment and poverty, growth in economic activities, as well as transformation in the informal sector. This has led to the introduction of a compulsory two-semester undergraduate course on entrepreneurship by the National Universities Commission (NUC) the regulatory body for university operations in Nigeria. This move as Aja-Okorie and Adali (2013) believes will inculcate necessary 
entrepreneurship knowledge and skills, to reduce graduate unemployment and high dependence on paid employment in Nigeria.

Bae, Qian, Miao and Fiet (2014), opine that entrepreneurial education refers to the learning process for entrepreneurial attitude, and skill while the entrepreneurial intention is the desire to start a firm. We align with these lines of thought, as our research will in addition to attitude and skill, argue that entrepreneurial education also includes entrepreneurial knowledgeknowledge about the role entrepreneurs play in the society and economy. This will go a long way to address the low entrepreneurship culture noticed among most Nigerian graduates, lay emphasis on the development of competence and reduce the high dependence on paid employment in a country where graduate unemployment is growing tremendously.

Increasing complexity in the world of today shows that there is a gap between what is learnt in schools and the requirement to function professionally (Achtenhagen and Grubb, 2001; Eraut, 1994). This can be said of entrepreneurship today as graduates seem not to be motivated by the entrepreneurship drive as expected; this is evident in the rising unemployment levels. Thus, the need to look beyond just entrepreneurial education and ensuring that it necessarily gives rise to competence. More so, the extant literature on entrepreneurial education - entrepreneurial intention relationship shows that little empirical research has focused on developing economies (Ajike et al., 2015; Byabashiaja and Katono, 2011), such as Nigeria and has reported inconsistent and ambiguous results (Lorz, Volery and Muller, 2011; Bae et al., 2014). These observed weaknesses in the literature are the gaps which this study sought to fill by examining the impact of entrepreneurial education on entrepreneurial intentions among a sample of Nigerian students.

\section{Theoretical background and conceptual framework}

\section{Entrepreneurship as a career option for Nigerian undergraduates}

The decision to take up entrepreneurship as a career choice is considered voluntary and conscious (Krueger et al., 2000). On this basis, it seems appropriate to analyze the processes leading to this decision. Gartner et al (1994), as well as Kyro and Carrier (2005), think that entrepreneurship is a process occurring over a time, in this sense, entrepreneurial intentions seem to be the first step in the process of venturing into the world of entrepreneurship (Lee and Wong, 2004). This aligns with Ajzen's $(1991,2005)$ theory of planned behaviour which posits that intention is the best predictor of action or behaviour. Irrespective of the fact that there exist unrealized intentions, it remains logical, safe and reasonable to first nurse an intention that will trigger the planning and other sets-up activities as a necessary precursor to entrepreneurial venturing (Ekundayo \& Babatunde, 2014). Entrepreneurial intention is not usually inherited, but can be learnt through educational training and development. This agrees with Athayde (2009) point of view that entrepreneurial attributes can be positively shaped by the educational programs that students are exposed to, that is, making entrepreneurship a career option for undergraduate students. The relevance of experience and education has been widely highlighted, mostly for the added knowledge it provides (Cooper, 1985, 1993). Linan (2004) asserts that greater knowledge will directly provide a greater level of awareness about the existence of any professional career option.

Turker and Selcuk (2009) argue that the literature on entrepreneurship shows that most of the scholars have focused on adult entrepreneurs. Henderson and Robertson (2000) support the view that relatively little is known about young adults' view on entrepreneurship. To address 
this weakness in the literature, this study takes a look at young adults (university undergraduates) who are still in the course of their training to assess their understanding and development of entrepreneurial attitudes, skills and knowledge.

\section{Theory of planned behaviour}

Ajzen (1985) proposed the theory of planned behaviour as an extension of the theory of reasoned action (Ajzen and Fishbien, 1975). Both the theory of reasoned action and the theory of planned behaviour assert that behaviour is a direct outcome of behavioural intention (Shih and Fang, 2004). The theory of planned behaviour incorporates the concept of perceived behavioural control, thus extending the boundary condition of pure volitional control as specified by the theory of reasoned action. According to Ajzen $(1985,1991)$, perceived behavioural control relates to the belief regarding an individual's access to the resources and opportunities required to perform a behaviour. Perceived behavioural control is added as an exogenous variable with a direct relationship with actual behaviour and an indirect relationship through behavioural intention. The direct relationship between perceived behavioural control and behaviour is significant when the behaviour in question has some likelihood of some of its aspect not been under volitional control and the perceptions of control over the behaviour are accurate. The structural link from perceived behavioural control to behavioural intentions shows the influential drive of control on behaviour through intentions (Madden, Ellen and Ajzen, 1992). This implies that the perception of low levels of control over performing behaviour results in low intentions to perform the behaviour. Perceived behavioural control encompasses two components- facilitating conditions and self-efficacy (Triandis, 1979; Ajzen, 1991). Facilitating conditions reflects the availability of the required resources needed to perform behaviour such as time, money and other resources. The second one, self-efficacy refers to the individual's confidence in the ability to successfully perform the behaviour (Bandura 1977, 1982). Given this explanation, a student with a self-assured skill, knowledge and attitude of enterprise is more inclined to take up entrepreneurship as a career option. Theories of competence development emphasise that learners must not only acquire but also integrate knowledge, skills and attitudes to achieve vocational competence (Eraut, 1994; Kaslow et al., 2007).

\section{Hypotheses formulation}

\section{Attitude and entrepreneurial intentions}

Entrepreneurial attitude covers aspects that help individuals to take action including taking responsibility for their own learning, careers and life. Personal attitude towards entrepreneurship has been measured unconditionally in some instances (Krueger et al, 2000) and in some other instances have been considered as opposed to paid employment (Kolvereid, 1996). However, this latter opinion is far from clear. There is evidence supporting the assertion that a large number of business owners today started their businesses as a part-time operation while in a paid employment (Carter, Gartner, \& Reynolds, 1996; Delmar \& Davidsson, 2000; Kolvereid \& Isaksen, 2006). Attitudes towards owning a business refer to the degree to which an individual holds positive or negative personal beliefs about been an entrepreneur (Ajzen, 2001; Autio et al., 2001). It includes both affective and evaluative considerationsattractiveness and advantageous. Entrepreneurship is an intentional and conscious attempt at been self-employed. It involves the use of well thought out and research-based results for a good decision. Bagozzi et al (1989) opine that intention is the single best predictor of planned behaviour. Understanding intentions, therefore, proves valuable particularly in the situation where the phenomenon is rare and involves unpredictable time lag such as entrepreneurship 
(MacMillan and Katz, 1992). Simply put, intentions predict behaviour while certain attitudes predict intention and so to understand the outcome of intentions such as actions and behaviours, antecedents of intention require being studied (Krueger et al., 2000). From the foregoing discussions, we hypothesise thus:

H1: Entrepreneurial attitude has a significant positive influence on entrepreneurial intentions among Nigerian undergraduates.

\section{Entrepreneurial Skills and entrepreneurial intentions}

Entrepreneurial skills concern the skills needed to turn ideas into action. Developing entrepreneurial skills and mindset is one of the main purposes of introducing entrepreneurial education in institutions of higher learning. Research has shown that more than developing some personality trait is to capture a mindset and attitudinal approach towards entrepreneurship (European Commission, 2012). Athayde (2009) opines that teaching students how to be entrepreneurs is possible only by helping them develop the entrepreneurial skills that are needed to turn their ideas into workable plans and action. These skills include creativity, analytics and adaptability. Creativity is the ability to connect ideas to solve societal problems (Bird, 1995) while analysis refers to the act of separating main ideas from supporting ideas and recognising patterns and consequences (De Jong, 2008). Adaptability involves mastering activities such as observation, interpretation, anticipation and response in that order. Successful entrepreneurs have been known to be those with the capacity to react to changes in their environment or the market (Oosterbeek, Hessel and Ijsselstein, 2010). In this way, they adopt views from different perspectives and try out new possibilities based on environmental needs. Individual creative skill is regarded as a basic requirement in paid employment and this can be responsible for successful innovation which entrepreneurship depends on (Nystrom, 1979). Based on the foregoing discussions, we hypothesise thus:

$\mathrm{H} 2$ : Acquisition of entrepreneurial skills will increase the potential of having entrepreneurial intentions among Nigerian undergraduates.

\section{Knowledge of entrepreneurship and entrepreneurial intentions}

Knowledge refers to having a broad understanding and knowledge of entrepreneurship including the role entrepreneurs and entrepreneurship plays in modern economies and societies (European Commission, 2012). Entrepreneurship education should improve the possibility of more entrepreneurs by increasing the knowledge of students and building their self-efficacy (Krueger and Brazeal, 1994). This will increase their desirability and perceived feasibility of entrepreneurial venturing by showing the high regard placed in the career choice and the role it plays in the society and economy (Souitaris, Zerbinati and Al-Laham, 2007). Peterman and Kennedy (2003) in their study found that students exposed to entrepreneurial education are more prone to desire entrepreneurship as a career option. However, he studied high school students rather than undergraduates. Hence we hypothesise that:

H3: Nigerian undergraduates who have entrepreneurial knowledge will be inclined to desire entrepreneurship as a career choice

\section{Attitude and entrepreneurial knowledge}

There has been an increasing recognition in the literature that several properties determine the strength of an attitude (Petty and Krosnick, 1995). Some attitudes are strong, enduring and consequential whereas others are weak in that they lack these features. Earlier researches have 
discussed and extensively investigated the construct of attitude-relevant knowledge which refers to some beliefs and experiences that come to mind in an event o encountering an attitude object (Davidson, 1995; Wood, Rhodes and Biek, 1995). Thus, knowledge is a structural property of attitudes (Fabrigar et al., 2006).

Researchers have been interested in knowledge and assume that increases in knowledge are associated with a greater influence of attitudes on behaviour. Kallgreen and Wood (1986) examined attitudes towards environmental protection and measured attitude-relevant knowledge; they found that attitudes based on high amounts of knowledge were more predictive of behaviour than attitudes based on low amounts of knowledge. In the same vein, Davidson et al (1985) found that intentions were better predictors of behaviours when they were based on more knowledge than when they were only a little knowledge. Based on the foregoing discussion, we hypothesize thus:

H4: Entrepreneurial attitude mediates the relationship between entrepreneurial knowledge and intentions.

\subsection{Conceptual model}

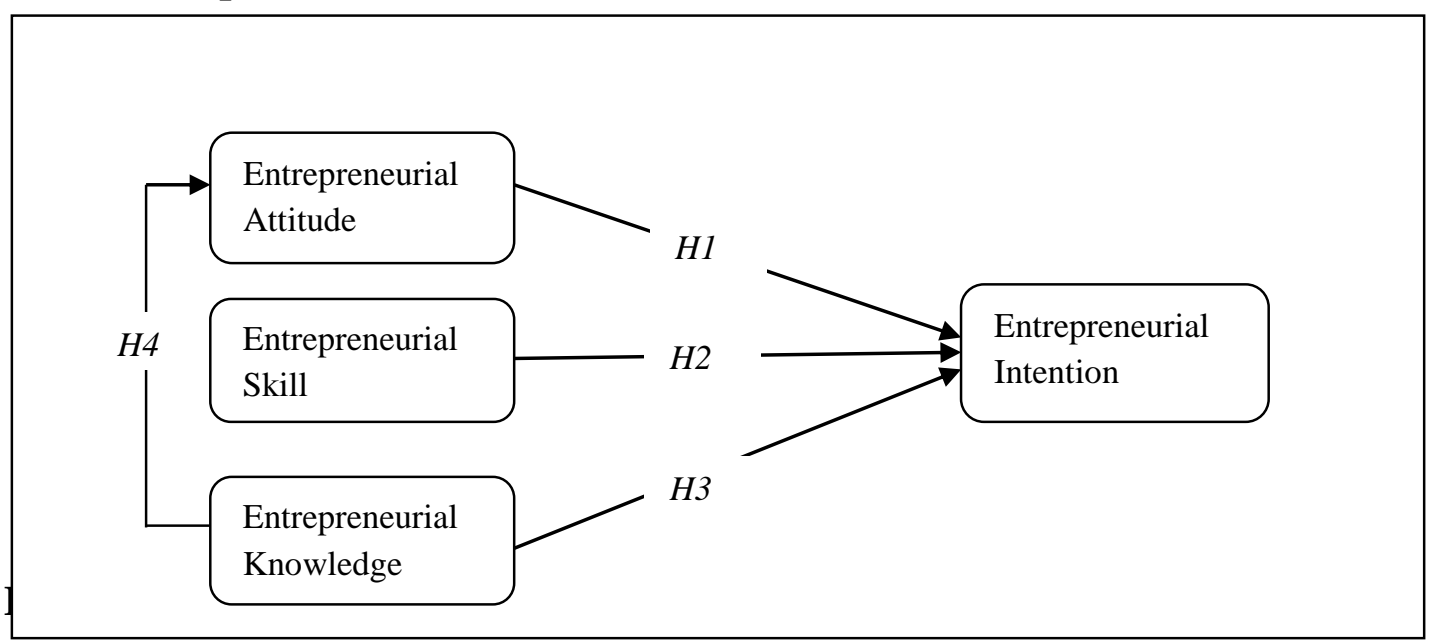

\section{Methodology}

\section{Measurement of the research constructs}

We operationalized entrepreneurial education as an outcome variable, seeking to break it down into components that arise from effective entrepreneurial education- attitudes, skills and knowledge. The scale items used in this study were adopted and modified from previous research studies. Scales for entrepreneurial attitudes, skills and knowledge were adapted from European Commission (2012) and Turker and Selcuk (2009). Similarly, the entrepreneurial intention was measured on a three-item scale adapted from Linan and Chen (2009).

\section{Sample and data collection}

All the scale items were measured in a five-point Likert format with 5 representing strongly agree and 1 representing strongly disagree and a middle point, 3 representing indecision.

The study sampled 250 undergraduate students using a self-administered questionnaire in Enugu metropolis, a city in South-eastern Nigerian. It is characterised by the presence of about 5 tertiary institutions including a Federal University (University of Nigeria, Enugu Campus), a state university (Enugu State University of Science and Technology) and several private 
universities and polytechnics. Of this number, only 196 valid responses were gathered representing $78.4 \%$ response rate.

The participants were purposively and conveniently approached to enable the collection of a large pool of data in a short time and at the same time reach out to only relevant respondents as the study sample are students who were at least in the third year of their tertiary education. The participants' demographics are as presented in Table I.

Table I: Respondents demographics

\begin{tabular}{lll}
\hline Variables & Count & Percentage \% \\
\hline Gender & 89 & 45.41 \\
Male & 107 & 54.59 \\
Female & & \\
Marital status & 157 & 80.10 \\
Single & 39 & 19.90 \\
Married & & \\
& 59 & 30.10 \\
Age & 124 & 63.27 \\
$<20$ & 13 & 6.63 \\
$21-35$ & & \\
36-50 & & \\
& 94 & 47.96 \\
Year of study & 43 & 21.94 \\
3rd year & 59 & 30.10 \\
4th year & & \\
5th year and above & & 91.33 \\
Religion & 179 & 8.67 \\
Christian & 17 & $\mathbf{1 0 0}$ \\
Moslem & $\mathbf{1 9 6}$ & \\
\hline Total & & \\
\hline
\end{tabular}

Field Survey, 2018

\section{Reliability and validity of research instrument}

In line with Hair et al (2014) two-step approach to assessing indicators reliability, the researchers adopted the conventional Cronbach Alpha and composite reliability for reliability test and afterwards construct validity was tested. From table II, the Cronbach alpha scores of the constructs, as well as the composite reliability scores, were well above the 0.7 minimum acceptable lower limits (Nunnally and Bernstein, 1994; Bagozzi and Yi, 1988). 
Table II: Items' factor loadings, $t$-statistics, reliability and validity (AVE)

\begin{tabular}{|c|c|c|c|c|c|c|}
\hline Construct & Indicators & $\begin{array}{l}\text { Factor } \\
\text { Loadings } \\
\end{array}$ & $t$-value & $\begin{array}{l}\text { Cronbach } \\
\text { alpha }(\alpha)\end{array}$ & $\begin{array}{l}\text { Composite } \\
\text { reliability }\end{array}$ & AVE \\
\hline \multirow{4}{*}{$\begin{array}{l}\text { Entrepreneurial } \\
\text { Attitude }\end{array}$} & EA1 & 0.834 & $49.712 * * *$ & \multirow[t]{4}{*}{0.723} & \multirow[t]{4}{*}{0.826} & \multirow[t]{4}{*}{0.647} \\
\hline & EA2 & 0.686 & $14.082 * * *$ & & & \\
\hline & EA3 & 0.589 & $12.143 * * *$ & & & \\
\hline & EA4 & 0.810 & $28.521 * * *$ & & & \\
\hline \multirow{3}{*}{$\begin{array}{l}\text { Entrepreneurial } \\
\text { Skill }\end{array}$} & ES1 & 0.781 & $35.379 * * *$ & \multirow[t]{3}{*}{0.887} & \multirow[t]{3}{*}{0.947} & \multirow[t]{3}{*}{0.619} \\
\hline & ES2 & 0.809 & $24.757 * * *$ & & & \\
\hline & ES3 & 0.843 & $44.174 * * *$ & & & \\
\hline \multirow{3}{*}{$\begin{array}{l}\text { Entrepreneurial } \\
\text { Knowledge }\end{array}$} & EK1 & 0.606 & $32.985 * * *$ & \multirow[t]{3}{*}{0.797} & \multirow[t]{3}{*}{0.881} & \multirow[t]{3}{*}{0.521} \\
\hline & EK2 & 0.953 & $46.349 * * *$ & & & \\
\hline & EK3 & 0.828 & $13.146^{* * *}$ & & & \\
\hline \multirow{3}{*}{$\begin{array}{l}\text { Entrepreneurial } \\
\text { Intention }\end{array}$} & EI1 & 0.725 & $24.193 * * *$ & \multirow[t]{3}{*}{0.781} & \multirow[t]{3}{*}{0.859} & \multirow[t]{3}{*}{0.597} \\
\hline & EI2 & 0.733 & $41.555 * * *$ & & & \\
\hline & EI3 & 0.807 & $38.421 * * *$ & & & \\
\hline
\end{tabular}

Note: Significant levels are denoted as $* * * p<0.05$

The instrument validity was also confirmed by examining convergent and discriminant validity. Construct validity is attained when both convergent and discriminant validity is met (Fornell and Larcker, 1981). An instrument can only attain convergent validity "if the average variance extracted (AVE) is 50 per cent or above" (Bagozzi and Yi, 1988; Fornell and Larcker, 1981), and the reflective indicators load significantly (Gefen and Straub, 2005) (i.e. $t$-value should be equal or above 1.96). As shown in Table II, the four constructs have AVE values ranging from 0.521 to 0.647 .

Table III: Construct correlations and discriminant validity

\begin{tabular}{lcccc}
\hline Constructs & $\begin{array}{l}\text { Entrepreneurial } \\
\text { Attitude }\end{array}$ & $\begin{array}{l}\text { Entrepreneurial } \\
\text { Skill }\end{array}$ & $\begin{array}{l}\text { Entrepreneurial } \\
\text { Knowledge }\end{array}$ & $\begin{array}{l}\text { Entrepreneurial } \\
\text { Intention }\end{array}$ \\
\hline EA & $\mathbf{0 . 8 0 4}$ & & & \\
ES & 0.599 & $\mathbf{0 . 7 8 7}$ & & \\
EK & 0.621 & 0.658 & $\mathbf{0 . 7 2 2}$ & \\
EI & 0.499 & 0.642 & 0.551 & $\mathbf{0 . 7 7 3}$ \\
\hline
\end{tabular}

Note: Square roots AVE are in bold italic print in the diagonal

Our measure of the psychometric properties of validity also displayed discriminant validity since the square root of the AVE of each construct is higher than the highest correlation pair of the constructs as shown in table III (Fornell and Larcker, 1981). 


\section{Structural model and test of hypotheses}

The proposed research hypotheses were examined through a partial least square structural equation modelling (PLS-SEM) technique in the SmartPLS 2.0 software (Ringle et al., 2005). Our preference for this SEM technique is based on its suitability for both normal and nonnormal data as well as small and medium sample sizes (Segarra-Moliner et al., 2013); also its ability to make predictions (Blunch, 2008). The initial structural outputs support all the proposed hypotheses as shown in table IV. A positive linear effect was found to exist between entrepreneurial attitude and entrepreneurial intention $(\beta=0.39 ; t=3.59 ; p<0.05)$. The relationship between entrepreneurial skills and entrepreneurial intention was also positive and significant $(\beta=0.22 ; t=7.98 ; p<0.05)$. Further, the effect of entrepreneurial knowledge on entrepreneurial intention was found to be positive and significant $(\beta=0.53 ; t=5.71 ; p<0.05)$. Finally, the indirect relationship between entrepreneurial knowledge and entrepreneurial intentions through entrepreneurial attitude was also positive and significant $(\beta=0.13 ; t=4.48$; $p<0.05$ ); implying that entrepreneurial attitude does transmit the effect of entrepreneurial knowledge onto intention.

In total, sixty-four per cent (64\%) of the variance in entrepreneurial intention was explained by the three variables. This implies that over $30 \%$ of the variations in the entrepreneurial intention are explained by other variables. Hence, the explanatory power of our model can be said to be strong.

Table IV: Estimated results of the structural model and hypotheses test outputs

\begin{tabular}{lllll}
\hline Hypothesized relationships & $\begin{array}{l}\text { Path } \\
\text { coefficient }\end{array}$ & $\begin{array}{l}\text { Standard } \\
\text { error }\end{array}$ & t-value & Result \\
\hline $\begin{array}{ll}\text { Direct } \text { effects } \\
H_{1} \quad \text { EA } \rightarrow \text { EI }\end{array}$ & 0.39 & 0.06 & $3.59 * * *$ & Supported \\
$H_{2} \quad$ ES $\rightarrow$ EI & 0.22 & 0.05 & $7.98^{* * * *}$ & Supported \\
$H_{3} \quad$ EK $\rightarrow$ EI & 0.53 & 0.06 & $5.71^{* * *}$ & Supported \\
$H_{4} \quad$ EK $\rightarrow$ EA & 0.13 & 0.04 & $4.48^{* * *}$ & Supported
\end{tabular}

Notes: Significant level is denoted as *** $p<0.05$

$\overline{E A=\text { Entrepreneurial attitude } ; E S=\text { Entrepreneurial skills; } E K=\text { Entrepreneurial knowledge; }}$ $E I=$ Entrepreneurial intention

\section{Discussion and limitations}

This study was initially set to examine the predictive power of entrepreneurial education on the intention to become entrepreneurs by undergraduates in Nigerian tertiary institutions. The paper draws on the theory of planned behaviour, a theory that posits that the immediate antecedent to any behaviour is the intention and had been extended to studies in various disciplines including marketing and psychology. We subsequently subjected our hypotheses to tests with the partial least square structural equation modelling (PLS-SEM) technique in SmartPLS 2.0 software. Our findings reveal that entrepreneurial attitude, skills and knowledge are direct predictors of entrepreneurial intentions. Also, the relationship between entrepreneurial attitude and knowledge is established. Our results also significantly add to the body of literature that postulated and confirmed the mediating role of intention and its predictive power to lead to behaviours. 
Our findings bear some relationship with earlier studies, we found an entrepreneurial attitude to have a significant positive impact on entrepreneurial intentions. This is in line with the studies by Krueger et al (2000), Carter et al (1996) and Delmar \& Davidson (2000). This clearly supports the theoretical position of Ajzen (1991) that intentions which predict behaviours are also predicted by some attitudes which are expressions of dispositions of the individuals to the attitude item. Invariably, the more positive attitude students have towards entrepreneurship, the greater intention they have towards taking up entrepreneurship as a career choice and vice versa.

Similarly, developing the skills of students while building their knowledge base and helping them form strong and positive attitudes was also found to be key to increasing their intention towards entrepreneurship. This finding aligns with those of Oosterbeek et al (2010) as well as Nystrom (1979). This also supports the opinion of Chell and Athalyde (2009) that teaching students how to be entrepreneurs is possible only by helping them develop the entrepreneurial skills that are needed to turn their ideas into workable plans and action.

In the same way, our findings agree with that of Krueger and Brazeal (1994) that increasing the knowledge base of students will build their self-efficacy and increase their intention of entrepreneurship. Also similar to our finding on entrepreneurial knowledge is the study by Peterman and Kennedy (2003). They found that exposure to entrepreneurial education increases student's intention towards becoming entrepreneurs. Finally, our proposition that entrepreneurial attitude mediates the relationship between entrepreneurial knowledge and entrepreneurial intention is confirmed by our findings and gives credence to the works of Davidson (1995), Wood et al (1995) as well as Kallgreen and Wood (1986) which believes that increase in knowledge is associated with a greater influence of attitudes on behaviour.

The study limitations include that, similar to other earlier studies, the entrepreneurial intention was the measure; this may not actually turn into actual behaviours in the future giving a lot of uncertainties about the future. Also, the results of this study may not be safe for generalisation as the sample was gotten from one developing country. It, therefore, implies that a need for conducting similar studies across countries and culture exists to overcome this limitation.

\section{Conclusion and implications}

Our point of departure is evident and relevant; the most important thing to be learnt from this empirical analysis is that the intention to become an entrepreneur depends not only on perceived feasibility and desirability, as traditional entrepreneurial intention models state, but also on the "entrepreneurial orientation" of the individual which is built majorly by the nature of entrepreneurial education the individual receives. This if properly done will lead to entrepreneurial competence and show the educational process as effective. From the point of view of education, it means that entrepreneurial training needs to consider the knowledge, skill and attitude towards entrepreneurship which will enable the individual to understand the concept of entrepreneurship, the role of the entrepreneurs and the skills and attitudes required for the development of the start-ups.

The results of our survey show that all the constructs in the proposed model were significant predictors of entrepreneurial intention. In line with our findings, if students are provided with good entrepreneurial knowledge, practicable skills, and form the right attitude, it is more likely that they will intend to choose entrepreneurship as a career choice. These findings emphasize the need for entrepreneurial education to create competence when done right. In the light of this, it is safe and logical to conclude that the entrepreneurial education in Nigerian tertiary 
institutions should be modified and the players inspired to become more effective and subsequently create competent potential entrepreneurs thereby reducing the high dependence on paid employment by the teeming youth population. This implies the need for more structural support and encouragement to develop creative ideas and build a knowledge base for intending entrepreneurs.

The second dimension of interest in the study findings is the role of entrepreneurial knowledge on entrepreneurial attitude. We found a significant effect of knowledge on attitude. In this case, it is expected that the more knowledge students gain of entrepreneurship and its role in the society and economy, they will form a positive attitude about entrepreneurship as a career option. Therefore, it is logical to state that entrepreneurial education is the immediate antecedent of entrepreneurial attitude.

\section{References}

Achtenhagen, F., \& Grubb, N. W. (2001), "Vocational and occupational education: Pedagogical complexity, institutional diversity", in Richardson V. (Ed.), Handbook of research on teaching. Washington, DC: AERA. pp. 604-639

Aja-Okorie and Adali (2013), "Achieving Youth Empowerment through Repositioning Entrepreneurial Education In Nigerian Universities: Problems And Prospects" European Scientific Journal, Vol. 3No. 9, pp 2-8

Ajike, O., Nnorom, K., Akinlabi, B.H., Onyia, A. \& Kwarbai, D. (2015). "Entrepreneurship education and entrepreneurship intentions: the role of theory of planned behaviour", International Journal of Advanced Research in Social Engineering and Development Strategies, Vol. 3 No 1, pp. 119.

Ajzen, I. (1991), "The theory of planned behaviour", Organizational Behavior and Human Decision Processes, Vol. 50, pp. 179-211.

Ajzen, I. (2001). Nature and operation of attitudes. Annual Review of Psychology, Vol 52, $27-$ 58.

Ajzen, I. (2005), Attitude, Personality and Behavior (2nd ed.). Open University Press, Poland, EU.

Athayde, R. (2009), "Measuring enterprise potential in young people", Entrepreneurship Theory and Practice, Vol. 33 No. 2, pp. 481-500.

Autio, E., Keeley, R. H., Klofsten, M., Parker, G. G. C., \& Hay, M. (2001), "Entrepreneurial intent among students in Scandinavia and the USA", Enterprise and Innovation Management Studies, Vol. 2 No.2, pp. 145-160.

Baartman, L.K.J and Bruijn, E. (2011), "Integrating knowledge, skills and attitudes: Conceptualising learning processes towards vocational competence", Educational Research Review, Vol. 6 No 2, pp. 125-134 
Bae, T.J., Qian, S., Miao, C. and Fiet, J.O (2014), "The relationship between entrepreneurship education and entrepreneurial intentions: a meta-analytic review", Entrepreneurship Theory and Practice, DOI: 10.1111/etap.12095

Bagozzi, R., Baumgartner, H., and Yi, Y. (1989), “An investigation into the role of intentions as mediators of the attitude-behaviour relationship" Journal of Economic Psychology Vol. 10 , pp. 35-62.

Bagozzi, R. P. and Yi, Y. (1988), "On the evaluation of structural equation models" Journal of the Academy of Marketing Science, Vol. 16 No. 1, pp. 74 - 94.

Bandura, A. (1977), Social learning theory. Prentice-Hall, Englewood Cliffs, NJ.

Bandura, A. (1982), "Self-efficacy mechanism in human agency", American Psychologist, Vol. 37 No. 2, pp. 122-147

Blunch, N. J. (2008), Introduction to structural equation modelling using SPSS and AMOS. Sage Publications Ltd, London.

Bridge, S., O’Neill, K., \& Cromie, S. (1998). Understanding enterprise, entrepreneurship and small firms, Macmillan, London.

Byabashaija, W. \& Katono, I. (2011), "The impact of college entrepreneurial education on entrepreneurial attitudes and intention to start a business in Uganda". Journal of Developmental Entrepreneurship, Vol. 16 No. 1, pp. 127-144.

Carter, N. M., Gartner, W. B., \& Reynolds, P. D. (1996), "Exploring start-up event sequences”, Journal of Business Venturing, Vol. 11 No. 3, pp. 151-166.

Crant, J. M. (1996), "The proactive personality scale as a predictor of entrepreneurial intentions", Journal of Small Business Management, Vol.34 No. 3, pp. 42-50.

Davidsson, P. (1995). "Determinants of entrepreneurial intentions” Working paper. Jönköping, Sweden: Jönköping International Business School.

Davidson, A. R., Yantis, S., Norwood, M., \& Montano, D. E. (1985), “Amount of information about the attitude object and attitude- behaviour consistency". Journal of Personality and Social Psychology, Vol. 49, pp. 1184-1198.

Delmar, F., \& Davidsson, P. (2000), "Where do they come from? Prevalence and characteristics of nascent entrepreneurs", Entrepreneurship and Regional Development, Vol. 12 No. 1, pp. 1-23.

Donckels, R. (1991), "Education and entrepreneurship experiences from secondary and university education in Belgium", Journal of Small Business and Entrepreneurship, Vol. 9 No 1, pp. 35-42. 
Ekundayo, B.B and Durowaiye, B.E (2014), "The impact of entrepreneurship education on entrepreneurial intentions among Nigerian undergraduates", International Journal of Research in Humanities, Arts and Literature, Vol. 2, No. 11, pp. 15-26

Eraut, M. (1994), Developing professional knowledge and competence, Routledge Falmer, London/New York, NY.

European Commission (2012), Effects and impact of entrepreneurship programmes in higher education. Brussels: DG Enterprise. European Commission

Fabrigar, L.R, Petty, R.E., Smith, S.M and Crites, Jr. A.L (2006), "Understanding knowledge effects on attitude-behaviour consistency: the role of relevance, complexity and amount of knowledge", Journal of Personality and Social Psychology, Vol. 90, No. 4, pp. 556-577

Fayolle, A., Gailly, B., \& Lassas-Clerc, N. (2006), "Assessing the impact of entrepreneurship education programmes: a new methodology". Journal of European Industrial Training, Vol. 30 No. 9, pp. 701-720.

Fishbein, M., \& Ajzen, I. (1975). Belief, Attitude, Intention and Behavior: an introduction to theory and research, Addison-Wesley, New York

Fornell, C., and Larcker, D. F., (1981), "Evaluating structural equation models with unobservable variables and measurement error". Journal of Marketing Research, Vol. 18 No. 1 , pp. $39-50$.

Galloway, L., \& Brown, W. (2002), "Entrepreneurship education at university: a driver in the creation of high growth firms?", Education and Training, Vol. 44 Nos. 8/9, pp. 398-405.

Gartner, W. B., Shaver, K. G., Gatewood, E. J., \& Katz, J. (1994), "Finding the entrepreneur in entrepreneurship", Entrepreneurship Theory and Practice, Vol. 18 No 3, pp. 5-10.

Gefen, D. and Straub, D. W. (2005) A practical guide to factorial validity using PLS-Graph: Tutorial and annotated example. Communications of the Association for Information Systems, Vol. 16, 91-109

Gorman, G., Hanlon, D., \& King, W, (1997), "Some research perspectives on entrepreneurship education, enterprise education \& education for small business management: A ten-year literature review", International Small Business Journal, Vol. 15 No. 3, pp. 56-77

Hair Jr., J. F., Sarstedt, M., Hopkins, L. and Kuppelweiser, V. G. (2014), "Partial least squares structural equation modelling (PLS-SEM): an emerging tool in business research", European Business Review, Vol. 26 No. 2, pp. 106 - 121.

Hager, P., Gonczi, A and Athanasou, J. (1994), "General issues about assessment of competence", Assessment and Evaluation in Higher Education, Vol. 19 No. 1, pp. 3-16

Henderson, R. and Robertson, M. (2000), "Who wants to be an entrepreneur? Young adult attitudes to entrepreneurship as a career", Career Development International, Vol. 5 No. 6, pp. 279-87. 
Kallgren, C. A., and Wood, W. (1986), "Access to attitude-relevant information in memory as a determinant of attitude-behaviour consistency", Journal of Experimental Social Psychology, Vol. 22, pp. 328-338.

Kaslow, N. J., Bebeau, M. J., Lichtenberg, J. W., Portnoy, S. M., Rubin, N. J., Leigh, et al. (2007), "Guiding principles and recommendations for the assessment of competence", Professional Psychology: Research and Practice, Vol. 38, pp. 441-451.

Katz, J.A. (2003), "The chronology and intellectual trajectory of American entrepreneurship education: 1876-1999”, Journal of Business Venturing, Vol. 18 No. 2, pp. 283-300.

Kolvereid, L. (1996), "Organizational employment versus self-employment: reasons for career intentions”, Entrepreneurship Theory and Practice, Vol. 20 No. 3, pp. 23-31.

Kolvereid, L., \& Isaksen, E. (2006), "New business start-up and subsequent entry into selfemployment", Journal of Business Venturing, Vol. 21 No. 6, pp. 866-885.

Krueger, N.F., Jr., Reilly, M.D. and Carsrud, A.L. (2000), "Competing models of entrepreneurial intentions", Journal of Business Venturing, Vol. 15 Nos 5/6, pp. 411-432.

Krueger, N.F. \& Brazeal, D.V. (1994), "Entrepreneurial potential and potential entrepreneurs", Entrepreneurship Theory and Practice, Vol. 18, pp. 91-104.

Kuratko, D.F. (2005), "The emergence of entrepreneurship education: Development, trends, and challenges", Entrepreneurship Theory and Practice, Vol. 29 No. 5, pp. 577-598.

Kyrö, P., \& Carrier, C. (2005), "Entrepreneurial learning in universities: bridges across borders", in P. Kyrö \& C. Carrier (Eds.), The dynamics of learning entrepreneurship in a cross-cultural university context, Hämmeenlinna, University of Tampere. pp. 14-43.

Lanero, A., Vázquez, J.L., Gutiérrez, P., \& García, M.P. (2011), "The impact of entrepreneurship education in European universities: An intention-based approach analyzed in the Spanish area", International Review on Public and Non-profit Marketing, Vol. 8 No. 2, pp. 111-130.

Lee, S. H., \& Wong, P. K. (2004), "An exploratory study of technopreneurial intentions: a career anchor perspective", Journal of Business Venturing, Vol. 19 No. 1, pp. 7-28.

Liñán, F. (2004), "Intention-based models of entrepreneurship education", Piccola Impresa / Small Business, Vol. 3, pp. 11-35.

Liñán, F. and Chen, Y.W. (2009), "Development and cross-cultural application of a specific instrument to measure entrepreneurial intentions", Entrepreneurship Theory and Practice, Vol. 33 No. 3, pp. 593-617.

Lizzio, A., and Wilson, K. (2004), "Action learning in higher education: An investigation of its potential to develop professional capability", Studies in Higher Education, Vol. 29, pp. 469-488. 
Lorz, M., Volery, T., \& Müller, C.A. (2011), "The impact of entrepreneurship education on entrepreneurial intention", Doctoral dissertation, The University of St. Gallen.

MacMillan, I., and Katz, J. (1992), "Idiosyncratic milieus of entrepreneurship research: The need for comprehensive theories", Journal of Business Venturing Vol. 7, pp. 1-8.

Madden, T.J., Ellen, P.S. and Ajzen, I. (1992), "A comparison of the theory of planned behaviour and the theory of reasoned action", Personality and Social Psychology Bulletin, Vol. 18 No. 1, pp. 3-9.

Matlay, H. and Carey, C. (2006). "Impact of entrepreneurial education on graduates in the UK: conceptual and contextual implications", in EFMD Entrepreneurship, Innovation and Small Business Conference (EISB) 36th Conference proceedings, Brussels.

National University Commission (2004), Labour market expectations of Nigerian graduates. Abuja: Education Trust Fund (ETF).

Nunnally, J. C. and Bernstein, I. H. (1994), Psychometric theory ( $3^{\text {rd }}$ Ed.), McGraw-Hill, New York

Nystrom, H. (1979), Creativity and Innovation, John Wiley and Sons, London, UK.

Oosterbeek, H., Van Praag, M., \& Ijsselstein, A. (2010), “The impact of entrepreneurship education on entrepreneurship skills and motivation", European Economic Review, Vol. 54 No. 3, pp. 442-454.

Peterman, N. E., \& Kennedy, J. (2003), "Enterprise education: influencing students' perceptions of entrepreneurship", Entrepreneurship Theory and Practice, Vol. 28 No. 2, pp. 129-144.

Petty, R. E., \& Krosnick, J. A. (Eds.). (1995), Attitude strength: Antecedents and consequences, Erlbaum, Mahwah, NJ.

Ringle, C. M., Wende, S. and Will, A. (2005), SmartPLS (Version 2.0 M3) [Software]. University of Hamburg, Hamburg, Germany. Available from: <http://smartpls.software.informer.com/2.0/> (Accessed 04 November 2018).

Robinson, P. B., \& Sexton, E. A. (1994), "The effect of education and experience on selfemployment success", Journal of Business Venturing, Vol. 9 No. 2, pp. 141-156.

Segarra-Moliner, J.-R., Moliner-Tena, M.-A. and Sanchez-Garcia, J. (2013), "Relationship quality in business to business: a cross-cultural perspective from universities", Marketing Intelligence \& Planning, Vol. 31 No. 3, pp. $196-215$.

Shane, S. and Venkataraman, S. (2000). "The promise of entrepreneurship as a field of research", Academy of Management Review, Vol. 25 No 1, pp. 217-226.

Shapero, A. (1981), "Self-renewing economies", Economic Development Commentary, 5(Ap), pp. 19-22. 
Shih, Y and Fang, K. (2004), "The use of a decomposed theory of planned behaviour to study Internet banking in Taiwan", Internet Research, Vol. 14 No. 3, pp. 213-223

Souitaris, V., Zerbinati, S., \& Al-Laham, A. (2007), "Do entrepreneurship programmes raise entrepreneurial intention of science and engineering students? The effect of learning, inspiration and resources", Journal of Business Venturing, Vol. 22 No. 4, pp. 566-591.

Triandis, H.C. (1979), Values, attitudes, and interpersonal behaviour, Nebraska Symposium on Motivation, Belief, Attitudes, and Values, University of Nebraska Press, Lincoln, NE, pp. 195-259

Turker, D. and Selcuk, S.S. (2009), "Which factors affect entrepreneurial intention of university students?", Journal of European Industrial Training, Vol. 33 No. 2, pp. 142159.

Wertch, J. V. (Ed.). (1981), The concept of activity in Soviet psychology, Sharp, New York, NY.

Wood, W., Rhodes, N., and Biek, M. (1995), "Working knowledge and attitude strength: An information-processing analysis", in R. E. Petty \& J. A. Krosnick (Eds.), Attitude strength: Antecedents and consequences, Erlbaum, Mahwah, NJ, pp. 283-313

Yoon, B.S. (2004), "Determinants of entrepreneurial intentions: individual characteristics and environmental factors", Korean Academic and Industrial Society of Business Administration, Vol. 17 No. 2, pp. 89-110.

Zhao, H., Hills, G. E., \& Siebert, S. E. (2005), "The mediating role of self-efficacy in the development of entrepreneurial intentions", Journal of Applied Psychology, Vol. 90 No. 6, pp. 1265-1272. 